\title{
Antiretroviral activity of Amazonian plants
}

\author{
Elida CG da Mata', Magda CA Gonçalves², Jorge FO Segovia ${ }^{3}$, Roberto M Bezerra ${ }^{4}$, José CT Carvalho ${ }^{4}$, \\ Luís IB Kanzaki ${ }^{*}$ \\ From Frontiers of Retrovirology 2011 \\ Amsterdam, The Netherlands. 3-5 October 2011
}

\section{Background}

The Amazon region displays a rich and diverse biota encompassing more than 50,000 botanical species [1]. A few medicinal plants commonly utilized by local people has been studied concerning its pharmacological properties. New antiretroviral drugs are on demand, mainly in developing countries and particularly in Brazil, which exhibit an exuberant biota, it is mandatory to rationally explore its immense and diverse floristic potential for medicinal purposes [2].

\section{Materials and methods}

Plants representatives of the Apocynaceae, Rubiaceae, Fabaceae, Caesalpiniaceae, Ochnaceae, Clusiaceae, Arecaceae, Chrysobalanaceae and Olacaceae families were collected in distinct geographic locations in the Amapa state, in the northern region of Brazil. Aqueous extracts of bark, leaves and fruits were prepared from the above botanical species. An established lymphoblastic cell line, H9, cultured in RPMI medium supplemented with fetal bovine serum and antibiotics was utilized to replicate the Simian Immunodeficiency Virus, strains SIVagm1554 and SIVmac186. Previously to SIV infection, H9 cells were cultured in a 48 plate at $5.95 \times 105$ density per well in $500 \mathrm{uL}$ and treated in high, median and low concentration of each aqueous plant extract and citotoxicity was evaluated by the WST assay. After determining the inocuous aqueous extract concentration, cells were treated with the plant extract and after 48 hours, cells were washed and infected with $599.64 \mathrm{pg} / \mathrm{mL}$ (SIVp27) of SIV. After 96 and 144 hours post infection, samples of cell supernatant were collected of each well and assayed for viral replication by measuring SIVp27 utilizing the SIVp27 Antigen Capture Assay (Advanced Bioscience Laboratory, Inc.) [3].

'Laboratory of Bioprospection, University of Brasília, DF, Brasília, Brazil, CEP 70.910-900

Full list of author information is available at the end of the article

\section{Results}

Of all plants aqueous extracts tested, 8 reduced SIV replication but just two, representatives of Fabaceae and Chrysobalanaceae families, did reduce virus replication but did not reduce cell density. Also, besides the antiretroviral activity found, proliferative and citotoxic activity was detected among the plants herein studied.

\section{Conclusions}

Ongoing studies aim at the identification of plant extract fractions exhibiting antiretroviral, proliferative and cytotoxic activities in order to plan future research work to develop new drugs.

\section{Acknowledgements \\ Viruses and cell lines were kindly donated by the NIH AIDS Research and Reference Reagent Program. Part of this research work was financed by Banco da Amazônia and University of Brasília.}

\section{Author details}

${ }^{1}$ Laboratory of Bioprospection, University of Brasília, DF, Brasília, Brazil, CEP 70.910-900. ²Secretary of Science and Technology, Macapá, AP, Brazil, CEP 68.901-335. '3razilian Agricultural Research Corporation, Macapá, AP, Brazil, CEP 68903-419. 'Laboratory of Drugs, Federal University of Amapá, Macapá, AP, Brazil, CEP 68902-280.

Published: 3 October 2011

\section{References}

1. Feeley KJ, Silman MR: Extinction risks of Amazonian plant species. P N A S, USA 2009, 106:12382-12387.

2. Correia AF, Segovia JFO, Gonçalves MSA, de Oliveira VL, Silveira D, Carvalho JCT, Kanzaki LIB: Amazonian plant crude extract screening for activity against multidrug-resistant bacteria. Eur Rev Med Pharmacol Sci 2008, 12(6):369-380.

3. Da Mata ECG: Avaliação de Atividade Antiretroviral de Plantas Amazônicas Utilizando Como Modelo o Vírus da Imunodeficiência Símia. Master Dissertation University of Brazil; 2011, 88.

doi:10.1186/1742-4690-8-S2-P87

Cite this article as: da Mata et al:: Antiretroviral activity of Amazonian plants. Retrovirology 2011 8(Suppl 2):P87.
() 2011 da Mata et al; licensee BioMed Central Ltd. This is an open access article distributed under the terms of the Creative Commons Attribution License (http://creativecommons.org/licenses/by/2.0), which permits unrestricted use, distribution, and reproduction in any medium, provided the original work is properly cited. 